\title{
Tough Ordered Mesoporous Elastomeric Biomaterials Formed at Ambient Conditions
}

Anand. K. Rajasekharan ${ }^{1}$, Christoffer Gyllensten ${ }^{1}$, Edvin Blomstrand ${ }^{1}$ Marianne Liebi ${ }^{2}$ and Martin Andersson ${ }^{1}$

${ }^{1}$ Department of Chemistry and Chemical Engineering, Chalmers University of Technology, Gothenburg SE-41296, Sweden

${ }^{2}$ Department of Applied Physics, Chalmers University of Technology, Gothenburg SE-41296,

Sweden

Email: martin.andersson@chalmers.se

\section{Supporting Information}

Table S1: Lattice spacing and fibril diameter of the hexagonally ordered referencePLLC and ME. ${ }^{1-2}$

\begin{tabular}{|c|c|c|c|c|}
\hline & Reference-LLC & Reference-PLLC & E-LLC & ME \\
\hline $\mathbf{q}_{\mathbf{1 0 0}}\left(\mathbf{n m}^{\mathbf{- 1}}\right)$ & 0.529 & 0.497 & 0.512 & 0.531 \\
\hline $\mathbf{a}_{\text {hex }}(\mathbf{n m})$ & 13.71 & 14.59 & 14.16 & 13.65 \\
\hline $\mathbf{r}_{\text {aq }}(\mathbf{n m})$ & 3.82 & 4.07 & 3.95 & 3.81 \\
\hline $\mathbf{d}_{\text {aq }}(\mathbf{n m})$ & 7.64 & 8.13 & 7.90 & 7.61 \\
\hline & 58.45 & 66.22 & 62.40 & 58.01 \\
$\mathbf{A}_{\text {hyp }}{ }^{* *}\left(\mathbf{n m}^{\mathbf{2}}\right)$ & & & & \\
\hline $\mathbf{r}_{\text {hyp }}(\mathbf{n m})$ & 4.31 & 4.59 & 4.46 & 4.30 \\
\hline $\left.\mathbf{d}_{\text {hyp }} \mathbf{( n m}\right)$ & 8.63 & 9.18 & 8.91 & 8.60 \\
\hline
\end{tabular}

$a_{\text {hex }}=\frac{4 \pi}{\sqrt{3}} \times \sqrt{h^{2}+h k+k^{2}} \times \frac{1}{q_{100}}$

$r_{a q}=a_{\text {hex }} \times \sqrt{\frac{\sqrt{3}}{2 \pi} \times(1-f)}$ where $1-f=\emptyset_{w}+0.27 \emptyset_{p}$

$\emptyset_{w}=$ volume fraction of water in the $L L C$;

$\emptyset_{p}=$ volume fraction of MP123 in the $L L C ; 0.27$ is volume fraction of PEO chains in MP123

** See Figure S1, values calculated by assuming the hydrophobic domain is a circle inscribed in an equilateral triangle of side $A_{\text {hex }}$ 


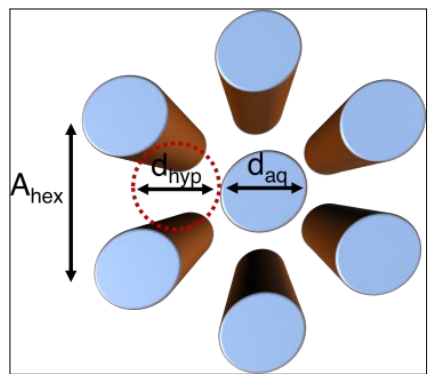

Figure S1: Hexagonal E-LLC structure and quantifiable dimensions of the structure.

Table S2: Compositions of additional E-LLC phases with different nanostructures used to verify the phase behaviour of MP123-water-MMA system. ${ }^{1}$

\begin{tabular}{|c|c|c|c|c|c|}
\hline & $\begin{array}{c}\text { Nanostructu } \\
\text { re }\end{array}$ & $\begin{array}{c}\text { MP123 } \\
\text { (wt\%) }\end{array}$ & Water (wt\%) & BuAc (wt\%) & MMA (wt\%) \\
\hline \multirow{4}{*}{ Reference-LLC } & $\begin{array}{c}\text { Hexagonal } \\
\text { NMF }\end{array}$ & 50 & 15 & 35 & - \\
\hline & $\begin{array}{c}\text { Lamellar } 1 \\
\left(\mathrm{~L}_{\alpha 1}\right)\end{array}$ & 30 & 60 & 10 & - \\
\hline & $\begin{array}{c}\text { Lamellar } 2 \\
\left(\mathrm{~L}_{\alpha 2}\right)\end{array}$ & 50 & 30 & 20 & - \\
\hline & $\begin{array}{c}\text { Micellar cubic } \\
\left(\mathrm{I}_{2}\right)\end{array}$ & 35 & 12.5 & 52.5 & - \\
\hline \multirow{4}{*}{ E-LLC } & $\begin{array}{c}\text { Hexagonal } \\
\text { NMF }\end{array}$ & 50 & 15 & - & 35 \\
\hline & $\begin{array}{c}\text { Lamellar } 1 \\
\left(\mathrm{~L}_{\alpha 1}\right)\end{array}$ & 30 & 60 & - & 10 \\
\hline & $\begin{array}{c}\text { Lamellar } 2 \\
\left(\mathrm{~L}_{\alpha 2}\right) \\
\end{array}$ & 50 & 30 & - & 20 \\
\hline & $\begin{array}{c}\text { Micellar cubic } \\
\left(\mathrm{I}_{2}\right)\end{array}$ & 35 & 12.5 & - & 52.5 \\
\hline
\end{tabular}


Reference and E-LLC Gels

Lamellar phase $1\left(\mathrm{~L}_{\alpha 1}\right)$

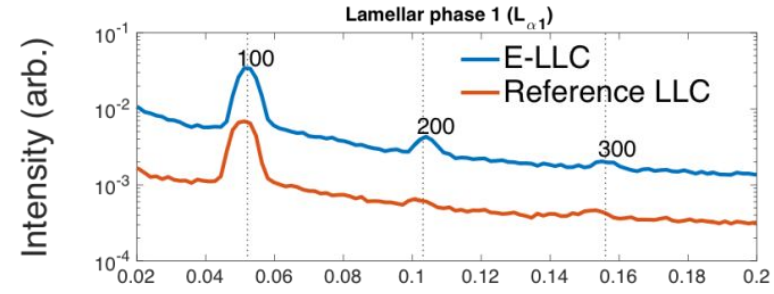

Lamellar phase $2\left(L_{\alpha 2}\right)$
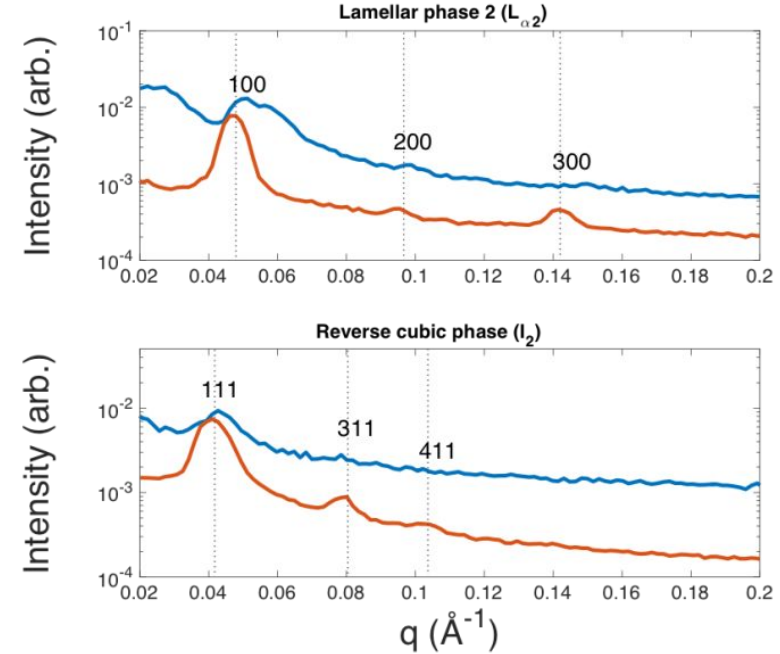

After crosslinking
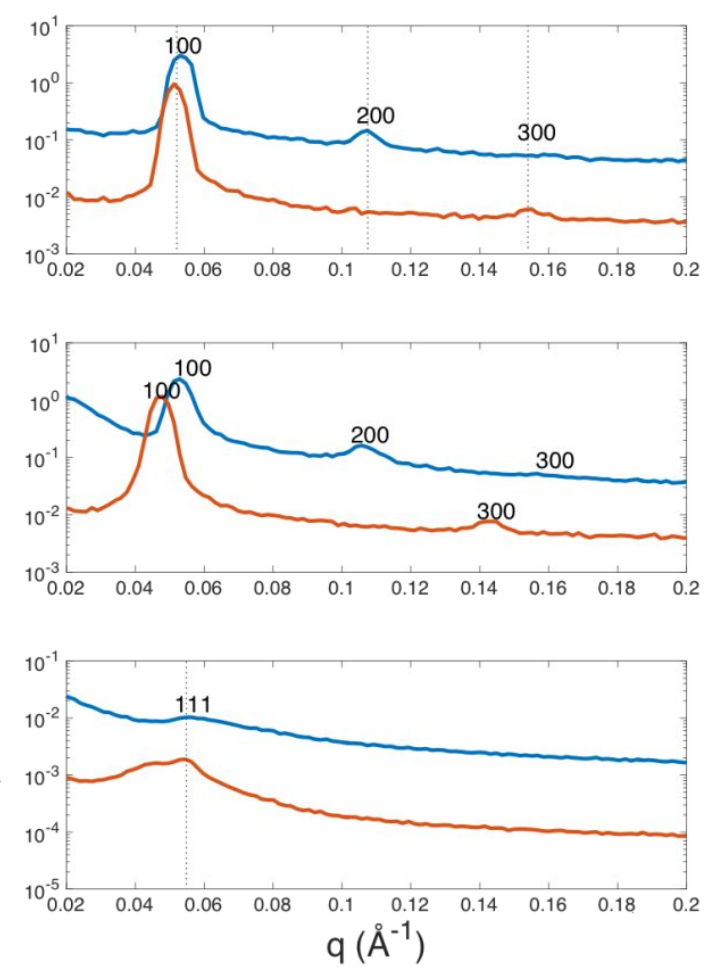

Figure S2: SAXS data of lamellar and cubic phases of the reference-LLC and E-LLC phases. Data confirms that MP123-water-MMA system forms a lyotropic mixture that is capable of forming different LLC phases.
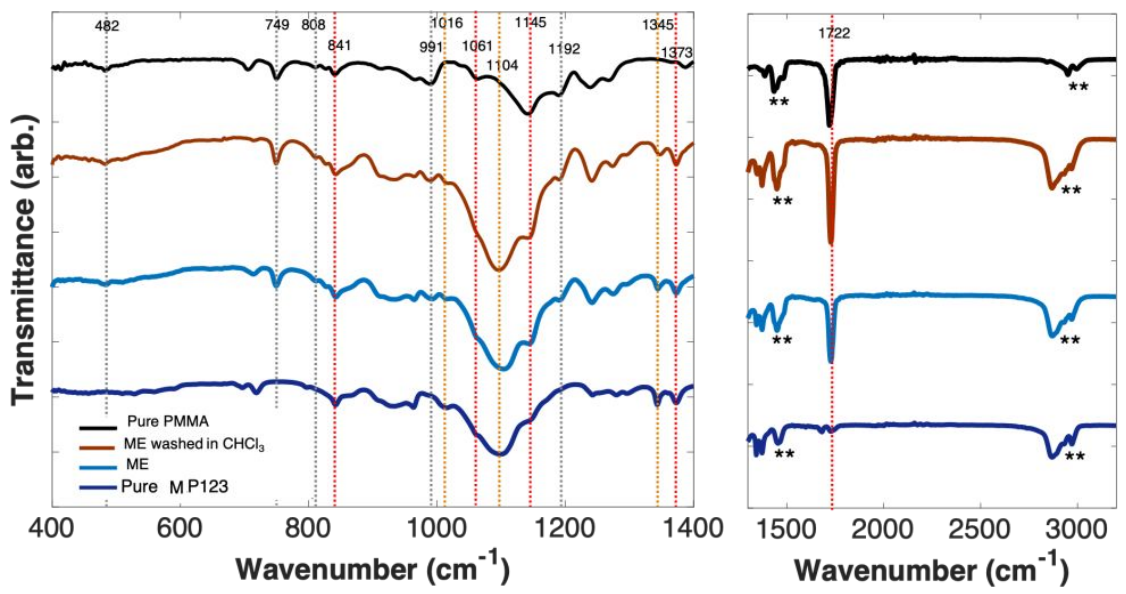

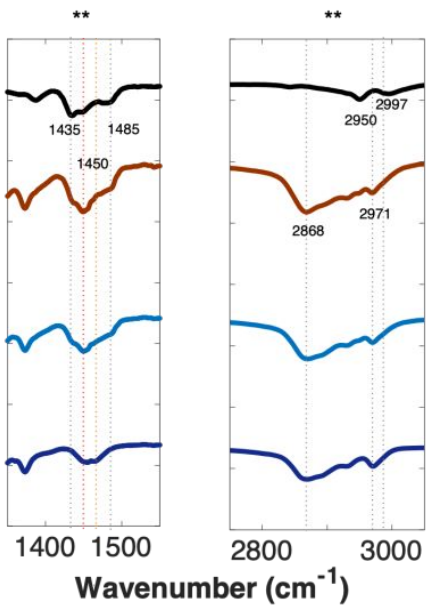

Figure S3: FTIR data of the ME (unwashed and washed in $\mathrm{CHCl}_{3}$ ) compared against pure MP123 and pure PMMA to identify understand the final chemical composition. 
Table S3: Correlation of FTIR signal to the chemical vibration in the different samples. ${ }^{3-4}$

\begin{tabular}{|c|c|c|c|}
\hline Wavenumber $\left(\mathrm{cm}^{-1}\right)$ & Pure PMMA & Pure MP123 & $\begin{array}{l}\text { ME (washed in } \\
\left.\qquad \mathrm{CHCl}_{3}\right)\end{array}$ \\
\hline 482 & $\begin{array}{c}\text { In plane bending } \mathrm{C}-\mathrm{C}- \\
\mathrm{O}\end{array}$ & & Present \\
\hline 749 & $\begin{array}{c}\mathrm{C}=\mathrm{O} \text { out of plane } \\
\text { bending }\end{array}$ & & Present \\
\hline 808 & C-O sym stretch & & Present \\
\hline 841 & $\mathrm{CH}_{2}$ rocking & $\mathrm{CH}_{2}$ rocking & Present \\
\hline 991 & $\begin{array}{c}\mathrm{C}-\mathrm{O} \text { stretch and in } \\
\text { plane bending of } \\
\mathrm{OCH}_{3}\end{array}$ & & Present \\
\hline $1016 \& 1061$ & & $\begin{array}{l}\mathrm{C}-\mathrm{O}-\mathrm{C} \text { asym stretch } \\
\text { and } \mathrm{CH}_{2} \text { sym. rock }\end{array}$ & Present \\
\hline 1104 & & C-O-C sym stretch & Present \\
\hline $1145 \& 1192$ & asym Stretch C-O-C & $\begin{array}{c}\text { asym stretch } \mathrm{C}-\mathrm{O}-\mathrm{C} \\
\text { C-C stretch }\end{array}$ & Present \\
\hline 1345 & & $\mathrm{CH}_{2}$ asym wag & Present \\
\hline 1373 & & $\mathrm{CH}_{3}$ sym deformation & Present \\
\hline 1387 & $\begin{array}{c}\text { In plane sym def of } \\
\mathrm{aCH}_{3}\end{array}$ & & Weak signal \\
\hline 1435 & $\begin{array}{l}\text { In plane sym def of } \\
\mathrm{OCH}_{3}\end{array}$ & & $\begin{array}{l}\text { Presence of all signals } \\
\text { especially matching } \\
\text { PMMA at } 1435 \text { and }\end{array}$ \\
\hline 1450 & $\begin{array}{l}\text { In plane asym defn of } \\
\mathrm{OCH}_{3}\end{array}$ & $\mathrm{CH}_{2}$ scissor & $\begin{array}{c}1485 \text { and MP123 and } \\
1449-1452\end{array}$ \\
\hline 1485 & $\begin{array}{l}\text { In plane asym def of } \\
\qquad \mathrm{aCH}_{3}\end{array}$ & & \\
\hline 1722 & $C=O$ stretch & $C=O$ stretch & Present \\
\hline 2868 & $\mathrm{C}-\mathrm{H}$ sym stretch in $\mathrm{CH}_{2}$ & $\mathrm{C}-\mathrm{H}$ sym stretch in $\mathrm{CH}_{2}$ & Present \\
\hline 2950 & $\begin{array}{c}\mathrm{C}-\mathrm{H} \text { asym stretch in } \\
\mathrm{CH}_{2}\end{array}$ & $\begin{array}{c}\mathrm{C}-\mathrm{H} \text { asym stretch in } \\
\mathrm{CH}_{2}\end{array}$ & Present \\
\hline 2971 & & $\mathrm{C}-\mathrm{H}$ stretch in $\mathrm{CH}_{3}$ & Present \\
\hline
\end{tabular}




\begin{tabular}{|l|l|l|l|}
\hline & & & \\
\hline 2997 & & $\begin{array}{c}\text { C-H asym stretch in } \\
\mathrm{aCH}_{3}\end{array}$ & Present, weak signal \\
\hline
\end{tabular}

Table S4: Stability of ME in Chloroform and 1M Sodium Hydroxide.

\begin{tabular}{|c|c|c|c|}
\hline & Initial weight (mg) & Final weight (mg) & Loss (\%) \\
\hline ME in $\mathrm{CHCl}_{3} 2$ days & 57.2 & 48.6 & 15.0 \\
\hline ME in Milli-q water, 2 days & 35.4 & 31.5 & 11.1 \\
\hline ME in 1M NaOH, 1 week & 8.9 & 7.8 & 12.4 \\
\hline Reference-PLLC in 1M NaOH, 1 week & \multicolumn{2}{|c|}{ Completely disintegrated within 3 hours } \\
\hline
\end{tabular}

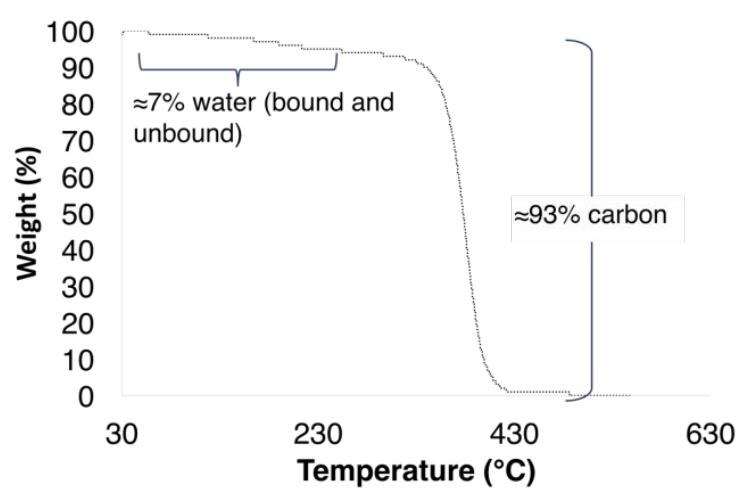

Figure S4: TGA data of the pristine ME.

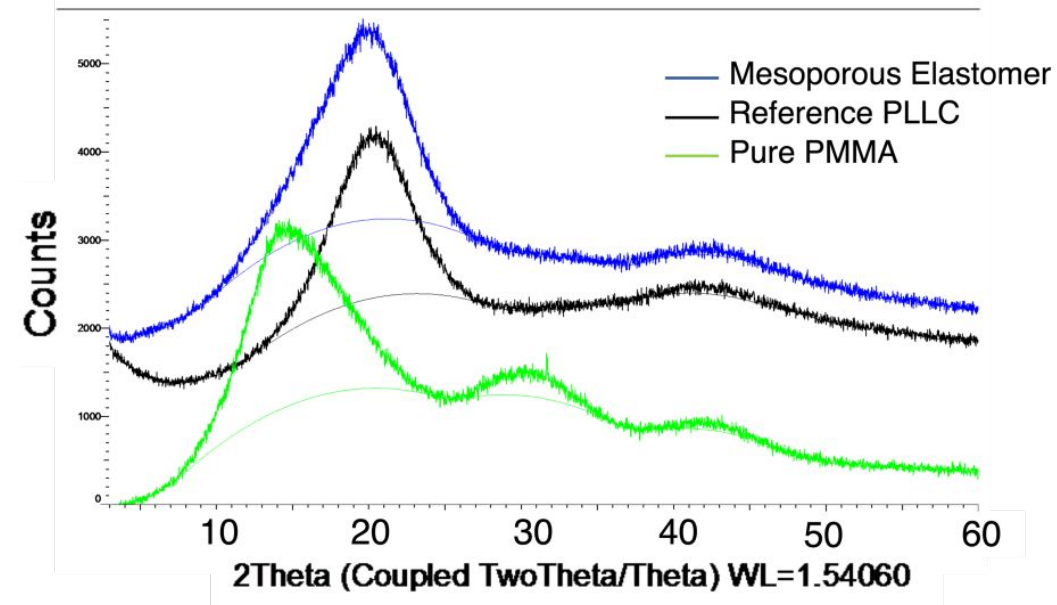

Figure S5: XRD data of the ME compared against reference-PLLC and pure PMMA 


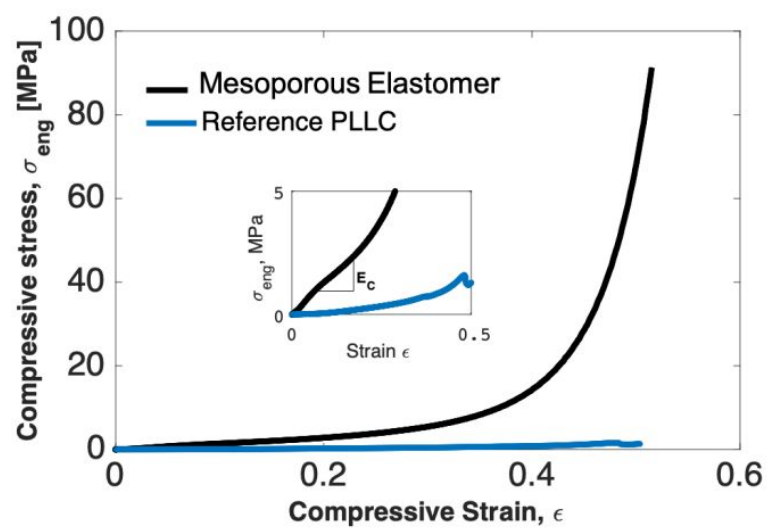

Figure S6: Compression data of the ME and reference-PLLC.

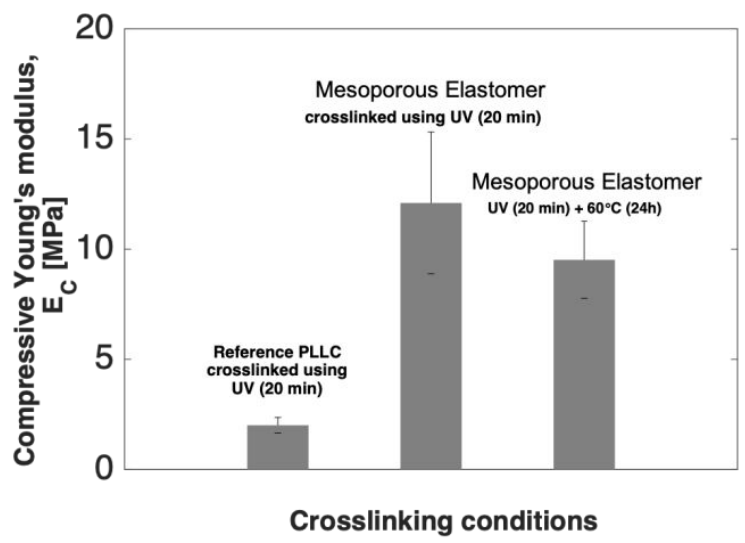

Figure S7: Elastic modulus of ME and reference-PLLC samples prepared using different crosslinking conditions.

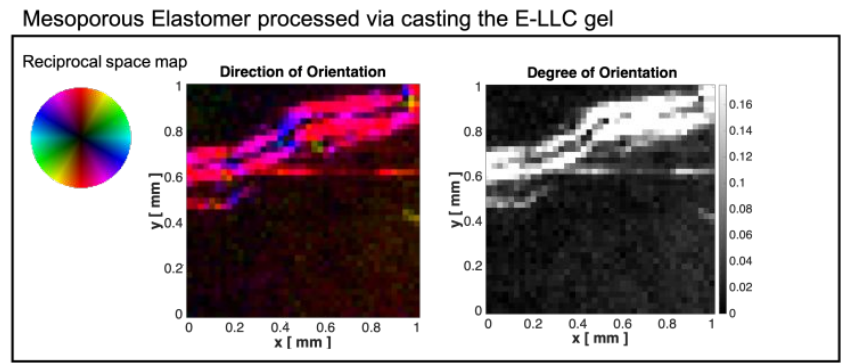

Mesoporous Elastomer processed via extrusion 3D printing the E-LLC gel
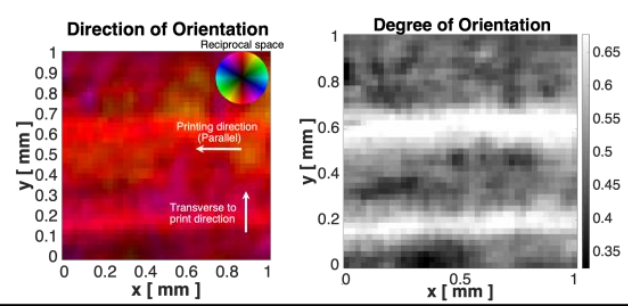

Figure S8: 2D SAXS data of ME fabricated via casting and 3D printing methods. The data shows how nanoscale micellar fibrils are oriented within the ME over millimeter 
length scales. As evident, the cast samples show poor to no long-range orientation while the printing uniformly aligns the nanostructure over macroscopic length scales.

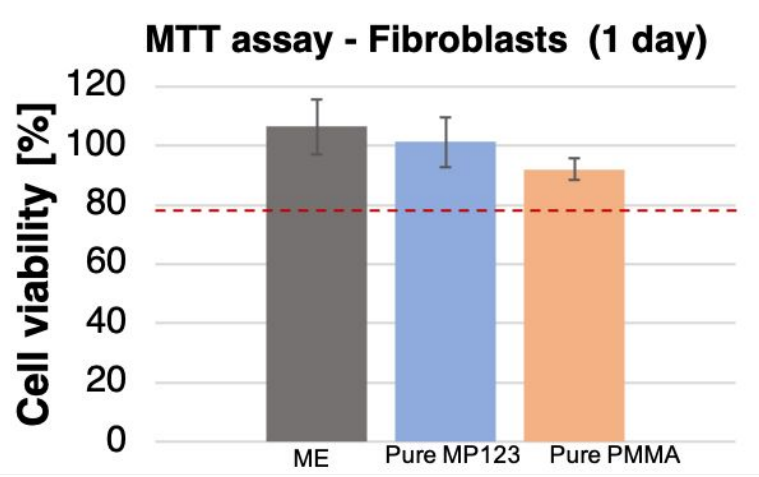

Figure S9: MTT assay results showing the HDFa cell viability for ME samples, pure MP123 samples and pure PMMA samples. ( $n=4$ for positive control, $n=4$ for $M E, n=3$ for pure MP123 crosslinked, $n=2$ for pure PMMA). The red dashed line represents $75 \%$ cell viability.

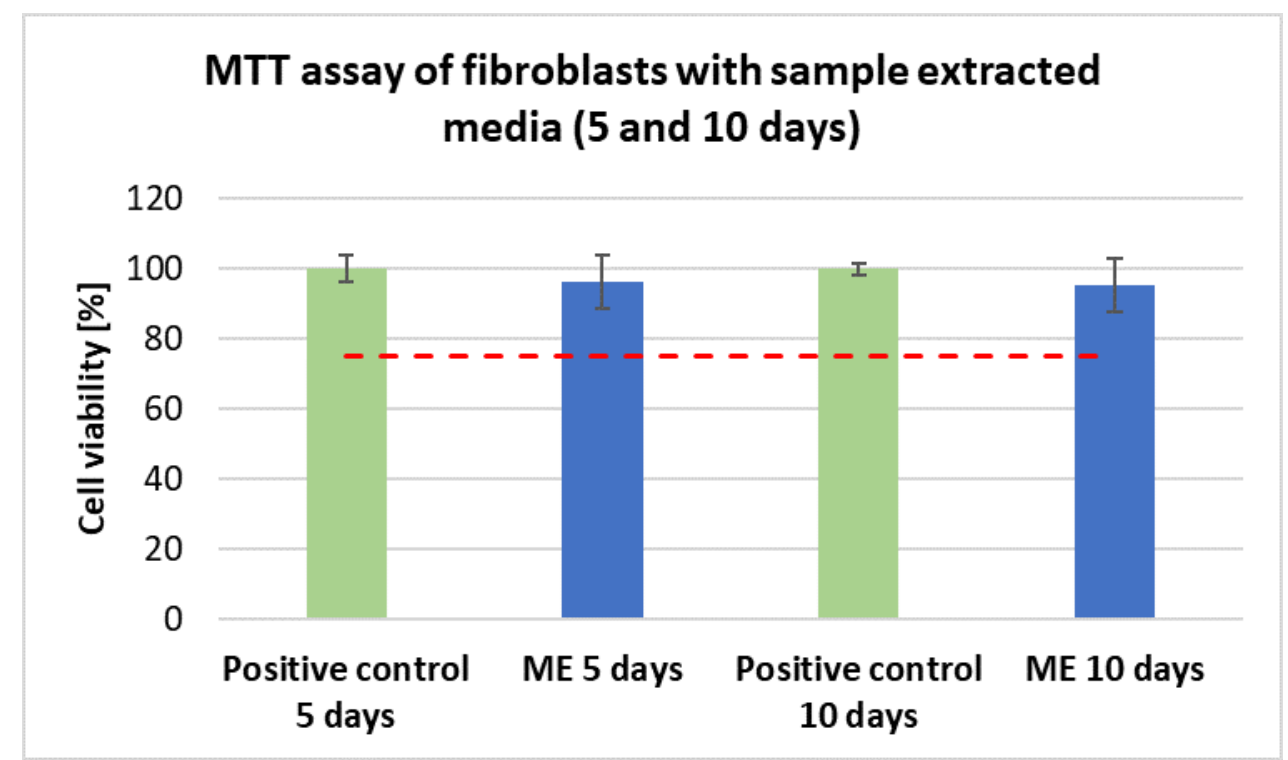

Figure S10: MTT assay results showing the primary HDFa cell viability with ME sample exposed media that was exposed to ME for 5 and 10 days. Cell viability was assessed after 3 days of cell-media exposure. ( $n=8$ for positive control, $n=8$ for ME). The red dashed line represents $75 \%$ cell viability.

Supporting Text 1: Sub culturing of cells: This was performed by discarding the existing media from the culturing flask followed by washing the flask with $2 \mathrm{~mL}$ Dulbecco's phosphatebuffered saline (DPBS) for 10-15 seconds. This process rinsed the cell culture from any chelators. A solution of $4 \mathrm{~mL}$ Trypsin/EDTA (0.025\% trypsin and 0.01\% EDTA in PBS) was then 
added for 20 seconds. Approximately $3 \mathrm{~mL}$ of the solution was removed and the cells were incubated at room temperature in $1 \mathrm{~mL}$ of Trypsin/EDTA. After 5 minutes, the cells started to round up and detach from the surface. Following this, the flask was gently shaken in order to detach the cells from the surface. A small amount of growth medium $(1 \mathrm{ml})$ was added to stop the trypsinization. The solution containing the cells was centrifuged for 5 minutes at 200 relative centrifugal force (RCF). The supernatant was discarded and the cells were resuspended in $1 \mathrm{~mL}$ of growth medium. The number of cells in solution was calculated using a Bürker chamber. Around 75000 cells were transferred into a new $25 \mathrm{~cm}^{2}$ culturing flask containing $5 \mathrm{~mL}$ growth medium. The flask was incubated at $37^{\circ} \mathrm{C}$ and $5 \% \mathrm{CO}_{2}$ with regular replacement of the media. The number of cells in the resuspended media was calculated using Equation 1.

$$
\text { Number of cells per } m L=\frac{\text { Counted cells }}{\text { Counted surface }\left(\mathrm{mm}^{2}\right) \times \text { Chamber depth }(\mathrm{mm})} \times 1000
$$

The volume transferred from the $1 \mathrm{~mL}$ resuspended solution into the new culturing flask was calculated using Equation 2.

$$
V_{\text {transferred }}=\frac{75000}{\text { Number of cells per } m L}
$$
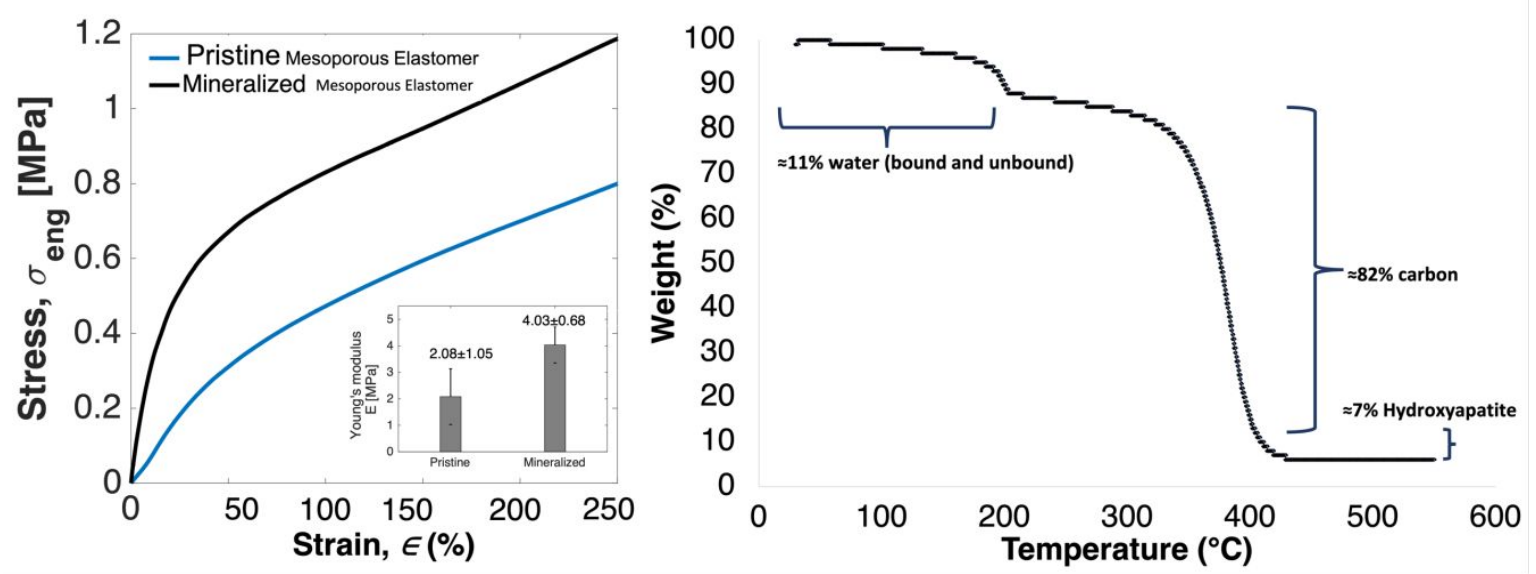

Figure S11: (Left) Tensile stress-strain curve of the mineralized ME and pristine $M E$, inset shows Young's modulus of the two samples. (Right) TGA plot of the mineralized $\mathrm{ME}$ shows the presence of $7 \%$ by weight hydroxyapatite in the material.

Table S5: Dry weight of samples before and after being soaked in $0.25 \mathrm{~mL} 10 \mathrm{w} / \mathrm{w} \%$ drug solution and corresponding percent increase in weight.

\begin{tabular}{|c|c|c|c|}
\hline ME with... & $\begin{array}{c}\text { Weight before soaking } \\
\text { (g) }\end{array}$ & $\begin{array}{c}\text { Weight after soaking } \\
\text { (g) }\end{array}$ & $\begin{array}{c}\text { Mean weight } \\
\text { increase (\%) }\end{array}$ \\
\hline Ibuprofen & 0.0075 (acetone) & 0.0112 & \\
\hline
\end{tabular}




\begin{tabular}{|c|c|c|c|}
\hline Ibuprofen & 0.0056 (acetone) & 0.0073 & 39.85 \\
\hline Vancomycin & 0.0084 (Milli-q water) & 0.0086 & \multirow{2}{*}{5.65} \\
\hline Vancomycin & 0.0079 (Milli-q water) & 0.0086 & \\
\hline
\end{tabular}

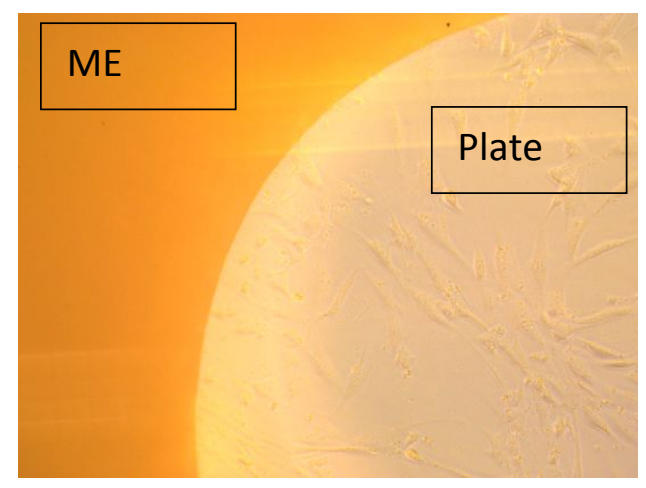

Figure S12: Bright field microscopy of the ME and human dermal fibroblast (HDFa) cells after contact for 2 days. Note that all cells prefer to attach to the underlying tissue culture plate. The turbidity of the ME also interferes with the imaging using inverted microscope.

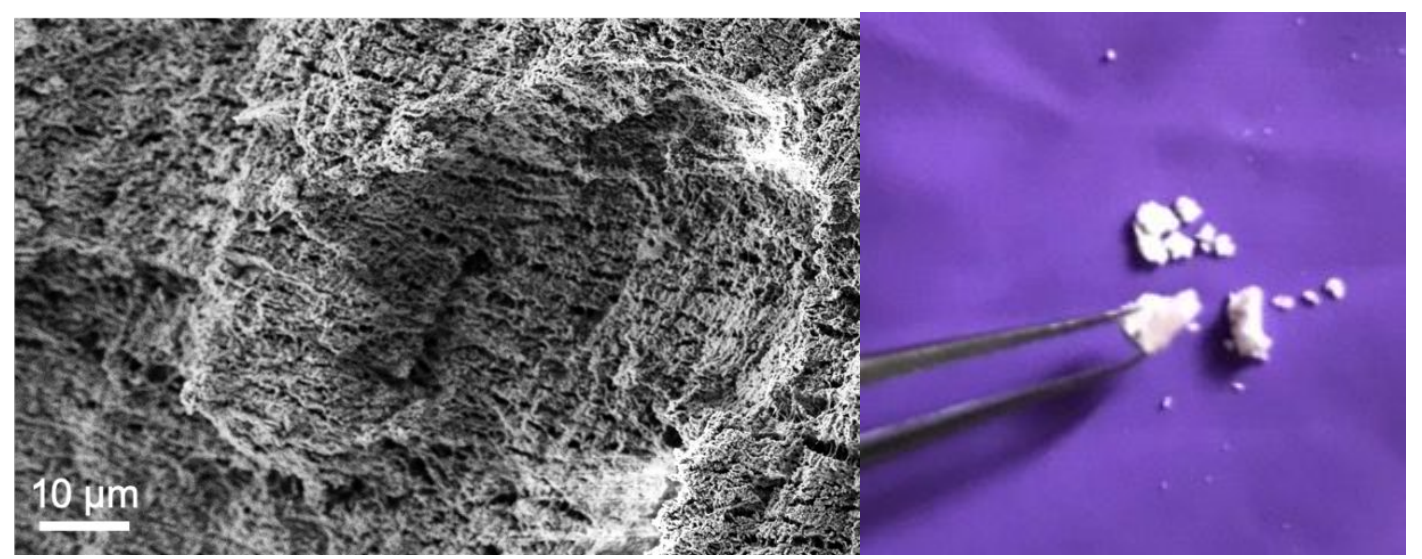

Figure S13: (Left) Microstructure of sample prepared from non-modified P123-water and MMA. Note the highly porous and disorganized structure. (Right) Powdery brittle substance recovered from the making a sample consisting of non-modified P123 and MMA of the same composition presented in the Mesoporous Elastomer. This is the reason that the MP123 and MMA must crosslink together to obtain the tough elastomeric properties. SEM images were taken in the same manner described in the Manuscript Methods section.

\section{REFERENCES}

1. Holmqvist, P.; Alexandridis, P.; Lindman, B., Modification of the Microstructure in Block Copolymer-Water-"Oil" Systems by Varying the Copolymer Composition and the "Oil" Type: Small-Angle X-Ray Scattering and Deuterium-NMR Investigation. J. Phys. Chem. B 1998, 102, 1149-1158.

2. Rajasekharan, A. K.; Andersson, M., Role of Nanoscale Confinement on Calcium Phosphate Formation at High Supersaturation. Cryst. Growth Des. 2015, 15, 27752780. 
3. Bensaid, M. O.; Ghalouci, L.; Hiadsi, S.; Lakhdari, F.; Benharrats, N.; Vergoten, G., Molecular Mechanics Investigation of Some Acrylic Polymers Using SPASIBA Force Field. Vib. Spectrosc. 2014, 74, 20-32.

4. Tanushree, B.; Robert Denis, G.; Munuswamy, V.; Jeffrey, F. G.; Saibal, R.; Kevin, M. R., Block Copolymer Mediated Stabilization of Sub-5 nm Superparamagnetic Nickel Nanoparticles in an Aqueous Medium. Nanotechnology 2009, 20, 415603. 